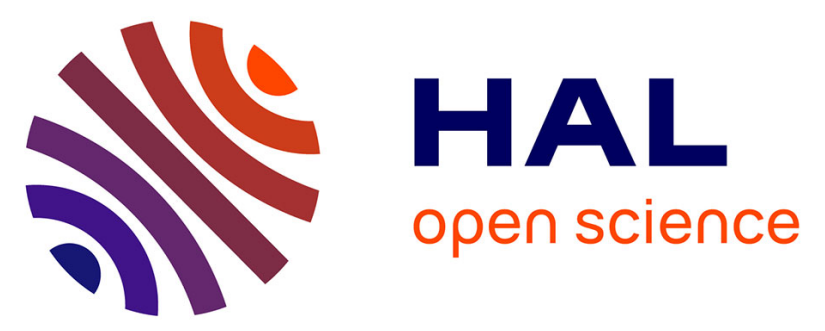

\title{
Characterisation of adult green lacewing (Chrysoperla carnea) digestive physiology: impact of a cysteine protease inhibitor and a synthetic pyrethroid
}

Evan A. Mulligan, Nathalie Ferry, Lise Jouanin, Joerg Romeis, Angharad

M.R. Gatehouse

\section{To cite this version:}

Evan A. Mulligan, Nathalie Ferry, Lise Jouanin, Joerg Romeis, Angharad M.R. Gatehouse. Characterisation of adult green lacewing (Chrysoperla carnea) digestive physiology: impact of a cysteine protease inhibitor and a synthetic pyrethroid. Pest Management Science, 2010, 66 (3), pp.325-336. 10.1002/ps.1879 . hal-01203923

\section{HAL Id: hal-01203923 \\ https://hal.science/hal-01203923}

Submitted on 31 May 2020

HAL is a multi-disciplinary open access archive for the deposit and dissemination of scientific research documents, whether they are published or not. The documents may come from teaching and research institutions in France or abroad, or from public or private research centers.
L'archive ouverte pluridisciplinaire HAL, est destinée au dépôt et à la diffusion de documents scientifiques de niveau recherche, publiés ou non, émanant des établissements d'enseignement et de recherche français ou étrangers, des laboratoires publics ou privés. 


\title{
Characterisation of adult green lacewing (Chrysoperla carnea) digestive physiology: impact of a cysteine protease inhibitor and a synthetic pyrethroid
}

\author{
Evan A Mulligan, ${ }^{a}$ Natalie Ferry, ${ }^{a}$ Lise Jouanin, ${ }^{b}$ Jörg Romeis ${ }^{c}$ \\ and Angharad MR Gatehouse ${ }^{a *}$
}

\begin{abstract}
BACKGROUND: In spite of concern regarding potential non-target effects of GM crops, few studies have compared GM pest control with conventional methods. The impacts of cypermethrin and oilseed rape expressing oryzacystatin-1 (OC-1) were compared in this study on the predator Chrysoperla carnea (Stephens).

RESULTS: Adults fed purified rOC-1 showed a subtle shift in digestive protease profile, with an increasing reliance on serine proteases (chymotrypsin), increase in aspartic proteases and a slight reduction in elastase activity. Although there were no effects on mortality, onset of oviposition was delayed; however, once egg production commenced, egg laying and hatching success rates were comparable with those of controls. Oryzacystatin-1 expressed in pollen showed no detrimental effects. Cypermethrin had no effect on mortality owing to high levels of non-specific esterase activity resulting in partial breakdown of the insecticide. In spite of this, there was a significant delay in onset of oviposition and a significant reduction in egg production and viability.

CONCLUSION: This study demonstrates the potential for pest management to impact on predators, but importantly it highlights the ability of the predator to detoxify/respond to treatments with different modes of action. In this case, exposure to an insecticide carried a greater fitness cost than exposure to a protease inhibitor expressed in transgenic crops.

(c) 2009 Society of Chemical Industry
\end{abstract}

Keywords: lacewing; Chrysoperla carnea; cypermethrin; transgenic crops; cysteine protease inhibitors

\section{INTRODUCTION}

Chrysoperla carnea (Stephens) is an important predator in agriculture. The value of this predator as a biological control agent arises not only from its widespread occurrence and broad range of prey but also from the fact that each of its three larval stadia are voracious polyphagous feeders, capable of consuming their own body mass in prey each day. ${ }^{1}$ It is thus important that the effects of insect pest control treatments on adults of $C$. carnea be minimised to ensure the production of successive generations of this biological control agent. ${ }^{2}$ The adult stages of $C$. carnea have a palyno-glycophagous diet, and are noted to feed on plant exudates, sap, honeydew, nectar and pollen. ${ }^{1}$ A recent study has shown that their ability to digest and utilise pollen is very high. ${ }^{3}$ With C. carnea larvae and pupae remaining in constant contact with the plant, and adults feeding directly on plant products, C. carnea has a potentially high exposure to plant protection chemicals.

Deleterious effects caused by herbicides, acaricides and insecticides on the survival and fecundity of beneficial insects have been well documented ${ }^{4-7}$ as have the effects of insecticides on C. carnea. ${ }^{8-10}$ Pyrethroids are the most widely used insecticide in many countries and in many different crops. Plapp and Bull ${ }^{11}$ reported that $C$. carnea larvae were relatively tolerant to synthetic pyrethroids compared with other classes of insecticide. Larvae of the lacewing have been shown to have a contact $L_{50}$ of $17000 \mu \mathrm{g} \mathrm{g}^{-1}$ for permethrin and can thus tolerate doses in excess of the recommended application rates; ${ }^{12}$ this value is also above that reported for many other resistant pests and beneficial insects. Tolerance may be due to a slow rate of pyrethroid binding and rapid clearance of these binding sites in neuronal sodium channels ${ }^{7}$ or to high levels and activity of esterases. ${ }^{12}$ Such increased tolerance was also linked to the ability of esterases rapidly to detoxify the cis-isomer of the common pyrethroids

\footnotetext{
Correspondence to: AngharadMRGatehouse, Institute of Research and Environmental Sustainability, School of Biology, University of Newcastle UponTyne, Newcastle NE1 7RU, UK. E-mail:a.m.r.gatehouse@ncl.ac.uk

a Institute of Research and Environmental Sustainability, School of Biology, University of Newcastle Upon-Tyne, Newcastle, UK

b Laboratoire de Biologie Cellulaire, INRA, Versailles, France

c Agroscope Reckenholz-Tänikon Research Station ART, Biosafety Group, Zurich, Switzerland
} 
permethrin and cypermethrin. cis-Isomers are the more toxic of the two common isomeric forms (cis and trans), and in many insect species esterases are only capable of detoxification of cis-isomers at a slow rate, and are thus unable effectively to protect the insect from pyrethroid toxicity. ${ }^{13}$ To the authors' knowledge, no work has been carried out to date on the specific mechanisms by which adult $C$. carnea tolerate pyrethroids.

The use of transgenic crops expressing $B t$ toxins is an evergrowing market, ${ }^{14}$ and today the impact of $B t$ maize and cotton varieties on natural enemies is relatively well understood. This includes C. Carnea, ${ }^{15,16}$ either when fed directly using artificial diets or when fed via the plant/pest/predator interaction. ${ }^{17-23}$ All stages of the lacewing may be exposed to transgene products, either directly or via tritrophic feeding. However, in spite of the fact that adults potentially have greater exposure levels to these products in cases where they are expressed in the pollen, there is only one study addressing the risks of $B t$ maize on the adult stage. ${ }^{3}$ Feeding adult $C$. carnea with $B t$ maize pollen expressing either Cry1Ab or Cry3Bb1 or elevated doses of the two toxins dissolved in an artificial diet does not cause any effect on a range of important life-table parameters.

Very little documented evidence exists on the impact of GM crops expressing non-Bt genes on C. carnea, although one study by Lawo and Romeis ${ }^{24}$ reported no detrimental effects of direct feeding on the protease inhibitor SBTI.

The potential for pest control measures based on the use of plant protease inhibitors (PIs) has long been noted. ${ }^{25}$ Biotechnology offers the opportunity both to increase expression of endogenous protease inhibitors and/or to express foreign inhibitors in crop plants. $^{26}$ Protease inhibitors have been shown to have the potential to control insect pests such as Lacanobia oleracea (L.), ${ }^{27}$ Plutella xylostella (L.), Mamestra brassicae (L.) ${ }^{28}$ and Chrysomela tremulae (F.). ${ }^{29}$ The efficacy of these protease inhibitors on insects is linked to a number of factors including their expression levels in plant tissues, the binding affinity between pest proteases and the protease inhibitor and the ability of the pest to adapt to inhibition.

The level of protease inhibitor expression is very important in providing effective control of pests, with low expression levels only achieving low levels of inhibition of digestive proteases, resulting in little effect either on insect development or on insect feeding patterns. ${ }^{28,30}$ High expression levels, on the other hand, can cause compensatory feeding effects in insects, thus causing an increase in crop damage. ${ }^{31}$ Insects can respond to protease inhibitors by altering their digestive proteases by increasing production of native enzymes ${ }^{31}$ or by synthesising insensitive forms of enzymes of the same or different mechanistic classes. ${ }^{32-39}$ The most successful examples of insect control via transgene expression of protease inhibitors result from use of protease inhibitors with a high affinity for the digestive protease in a targeted insect, as exemplified by Edmonds et al. ${ }^{40}$ Many PIs not only are effective against insect pests but also have the potential adversely to affect beneficial insects such as predators, either as a consequence of altered prey quality ${ }^{41,42}$ or by direct inhibition of the predator's digestive proteases.

As little information is currently available on the digestive proteases present in C. carnea, one of the aims of this study was to further characterise protein digestion in this important predatory species. The most recent work carried out on neuropteran insects has revealed the presence of an acidic gut, ${ }^{1,43}$ suggesting a predominance of cysteine forms of digestive proteases. The protease inhibitor selected for use in this trial was oryzacystatin $(\mathrm{OC}-1)$, a cysteine protease inhibitor that is thermodynamically stable and has been shown to have strong affinity for cysteine proteases in many different insects. ${ }^{36,40,44}$

The major aim of the study, however, was to compare the effects of two pest control strategies on life history parameters of the beneficial insect $C$. carnea, as well as effects on the digestive proteases and xenobiotic detoxifying enzymes [P450s and esterases (ESTs)]. The potential effects of cypermethrin, one of the most widely utilised pyrethroid pest control measures, were compared with pest control based on transgenic oilseed rape (OSR) expressing the cysteine protease inhibitor OC-1.

\section{MATERIALS AND METHODS}

\subsection{Insect cultures}

Stocks of $C$. carnea were raised from cultures maintained at the Agroscope Reckenholz-Tänikon Research Station ART, Zurich, Switzerland. Larval cultures were maintained on UV sterilised eggs of Ephestia kuehniella (Zeller) stored at $2-4{ }^{\circ} \mathrm{C}$. Adults were kept on an artificial diet (honey + yeast + water, $7+4+4$ ) in cages within controlled environment rooms at $22 \pm 3{ }^{\circ} \mathrm{C}$ and $70 \pm 5 \%$ $\mathrm{RH}$ under a 16:8 $\mathrm{h}$ light: dark photoperiod.

\subsection{Plant material}

Homozygous transgenic spring oilseed rape seed [Brassica napus (L.) cv. Drakkar, line OC-1 Drakkar 4B expressing the cysteine protease inhibitor oryzacystatin-1] was grown from seed generated as previously described by Bonadé-Bottino. ${ }^{45}$ Control B. napus cv. Drakkar was grown under identical conditions of a $16: 8 \mathrm{~h}$ light: dark photoperiod at a temperature of $20 \pm 2{ }^{\circ} \mathrm{C}$. Pollen was harvested and stored at $-80^{\circ} \mathrm{C}$ until required.

\subsection{Reagents}

EnzChek Protease assay kits (Molecular Probes) were obtained from Cambridge Bioscience, UK, and the ECL detection kit and chromatography resins were obtained from GE Healthcare, Amersham. Transepoxysuccinyl-L-leucylamido (4guanidio)butane (E-64), phenylmethylsulfonyl fluoride (PMSF), pepstatin $A$, ethylenediaminetetra-acetic acid disodium salt (EDTA), soybean Bowman-Birk inhibitor (SBBI) and papain were purchased from Bachem (UK) Ltd. Polyclonal antibodies were raised in rabbits by standard protocols against rOC-1. Cypermethrin $100 \mathrm{~g} \mathrm{~L}^{-1}$ EC (Pyrimet) was supplied by United Agricultural Products Ltd, Greets Farm, Welburn, North Yorkshire. Ethyl acetate used in GC detection of cypermethrin was obtained from Fisher and was HPLC grade. All other chemicals were from Sigma (Poole, UK) and were of analytical grade unless otherwise stated.

\subsection{Production of recombinant oryzacystatin (OC-1)}

Recombinant oryzacystatin ( $\mathrm{rOC}-1$ ) was purified from $E$. coli by ionexchange chromatography and purified according to the methods of Edmonds et al. ${ }^{40}$

\subsection{Insect bioassays}

Chrysoperla carnea were separated from stock culture at the pupal stage and stored individually in $10 \mathrm{~mL}$ sealed glass vials at $22 \pm 3{ }^{\circ} \mathrm{C}$ and $70 \pm 5 \% \mathrm{RH}$ under a 16:8 h light: dark photoperiod. Immediately after emergence, gender was determined and males and females separated. Groups of five insects were each placed into one of fourteen $250 \mathrm{~mL}$ sealed pots, with access to damp cotton and artificial diet treated for the appropriate group (seven 
pots of five males and seven pots of five females, $n=35$ per sex per treatment). After 5 days, individual male/female pairs were separated into $100 \mathrm{~mL}$ pots and provided with damp cotton, and were fed $5 \mu \mathrm{g}$ artificial diet per day for the remaining 17 days of the trial. Mortality and egg production was recorded daily throughout the trial. Egg hatching success was recorded for eggs laid on day 17 of the trial (day 17 was selected as it was only possible to assess hatching success once in the trial, and, on this day, high levels of oviposition occurred in all treatment groups). Hatching was classified as successful at the emergence of an L1 (first larval stadium). All adults in the trial were maintained in controlled environment rooms at $25 \pm 3^{\circ} \mathrm{C}$ and $70 \pm 5 \% \mathrm{RH}$ under a $16: 8 \mathrm{~h}$ light: dark photoperiod regime.

The four treatment groups were as follows (basic artificial diet: honey + yeast + water, $7+4+4)$ :

- control: artificial diet containing 1\% w/w control OSR pollen;

- OC-1 control: artificial diet containing $1 \% \mathrm{w} / \mathrm{w}$ control OSR pollen $+1 \%$ w/w rOC- 1 ;

- cypermethrin: artificial diet containing $1 \% \mathrm{w} / \mathrm{w}$ control OSR pollen and $19 \mu \mathrm{M}$ cypermethrin (1/100 dilution of recommended field application);

- OC-1 pollen: artificial diet containing $1 \% \mathrm{w} / \mathrm{w}$ OSR pollen expressing OC-1.

\subsection{Determination of transgene expression levels in OSR leaves and pollen}

Leaf samples were taken at random from transgenic and nontransformed control plants, flash frozen in liquid nitrogen, ground to a fine powder and extracted in $50 \mathrm{~mm}$ Tris- $\mathrm{HCl}$ buffer, $\mathrm{pH} 8.0$ (containing 1\% PMSF), as described previously. ${ }^{46,47}$ Extracts were centrifuged at $10000 \times g$ for $15 \mathrm{~min}$, and total soluble protein of the supernatants was estimated by Bradford assay ${ }^{48}$ with BSA as standard. For immunoassay by western blotting, samples (containing $50 \mu \mathrm{g}$ total protein) were separated on an SDS-PAGE $15 \%$ minigel, and proteins were transferred electrophoretically to a $0.2 \mu \mathrm{m}$ nitrocellulose filter. Oryzacystatin- 1 was detected by enhanced chemiluminescence (ECL), as previously described, ${ }^{46}$ using polyclonal antibodies raised in rabbits against recombinant OC-1 as the primary antibody, with HRP-conjugated goat antirabbit IgG (Bio-Rad laboratories, Hertfordshire, UK) as the secondary antibody; rOC-1 (produced in E. coli by L Ceci, Institute for Biomembranes and Bioenergetic-CNR, Trani, Italy) was used as a positive standard. Following positive confirmation of expression of OC-1 in OSR plants, pollen was collected and levels of expression within the pollen grains were determined via the addition of $1 \mathrm{~mL}$ of Tris- $\mathrm{HCl}$ buffer $(20 \mathrm{~mm}$; $\mathrm{pH} 7.5)$ to $1 \mathrm{mg}$ of pollen and sonication for $5 \times 1 \mathrm{~min}$. Following centrifugation at $13000 \times \mathrm{g}$ for $1 \mathrm{~min}$, samples were incubated overnight at $4{ }^{\circ} \mathrm{C}$ with agitation. Oryzacystatin- 1 expression was determined by ELISA, as described below. Similarly, OC-1 present in insect samples was also quantified by ELISA. Briefly, $50 \mu \mathrm{L}$ of insect gut extract, pollen preparation or purified OC-1 standards (to give final concentrations of $1-40 \mathrm{ng}$ of rOC-1 in PBS) was incubated for $1.5 \mathrm{~h}$ in sealed 96 -well microtitre plates. Unbound protein was removed by washing with PBS $+0.01 \% \mathrm{v} / \mathrm{v}$ Tween 20 (PBST), and the wells were blocked with bovine serum albumin (BSA; $20 \mathrm{mg} \mathrm{mL}^{-1}$ PBST) for $1.5 \mathrm{~h}$. Wells were again washed, incubated with primary antibody (anti OC-1 antisera; $1: 10000$ dilution) for $1 \mathrm{~h}$, rewashed and then incubated with secondary antibody (peroxidase-coupled antirabbit IgG; $1: 10000$ dilution) for $1 \mathrm{~h}$. The assay was developed by the addition of $50 \mu \mathrm{L}$ of $\mathrm{ABTS}^{\circledR}$ solution, and absorbance was read at $405 \mathrm{~nm}$ in a microtitre plate reader. Levels of OC-1 in insect samples and pollen extracts were determined from the OC-1 calibration curve. Assays were performed on each mg of pollen collected and on three separate samples of insect guts ( 5 guts sample ${ }^{-1}$ ); all assays were carried out in triplicate at room temperature.

\subsection{Determination of cypermethrin levels in Chrysoperla carnea guts by gas chromatography}

Cypermethrin levels in C. carnea were analysed by gas chromatography with electron capture detection using a Hewlett Packard 5890 series II operated at $50^{\circ} \mathrm{C}$, and a Hewlett Packard 6890 series injector with ECD radioactive source for detection, as described by Mulligan et al. ${ }^{47}$ Extracts were prepared from C. carnea guts. Known weights of digestive tract samples were extracted in ethyl acetate ( $1 \mathrm{~mL}$ ) for approximately $1 \mathrm{~min}$ by vortexing, then allowed to stand for a further $5 \mathrm{~min}$. The extract $(0.5 \mathrm{~mL})$ was dried under nitrogen and then reconstituted in ethyl acetate $(50 \mu \mathrm{L}$, using a microsyringe), thus equating to a tenfold concentration. The reconstituted extract was mixed using a vortex mixer, sonicated to ensure that the extract was fully redissolved, transferred to a $2 \mathrm{~mL}$ clear vial containing a $250 \mu \mathrm{L}$ tapered insert and analysed by GC-ECD.

\subsection{Demonstration of proteolytic activity in guts of Chrysoperla carnea}

Digestive tracts from the different developmental stages of C. carnea were dissected into chilled distilled water (1 gut section to $20 \mu \mathrm{L}$ ), homogenised on ice and centrifuged at $14000 \times g$ for $10 \mathrm{~min}$ at $4{ }^{\circ} \mathrm{C}$; the supernatants were precipitated with ammonium sulfate (to $65 \%$ saturation) and finally dialysed overnight at $4{ }^{\circ} \mathrm{C}$ against distilled water. Extracts from the different larval stadia and from male and female adults were kept separately so that subsequent activity could be related to the different developmental stages. General proteolytic activity was determined using the fluorescent protein substrate BODIPYFL casein. Chrysoperla carnea extract $(2 \mu \mathrm{L})$ from L1/L2/L3/adult female/adult male was incubated with $50 \mathrm{~mm}$ buffer $(188 \mu \mathrm{L})$ at $25^{\circ} \mathrm{C}$. The reaction was initiated by the addition of $10 \mathrm{~mm}$ substrate $(10 \mu \mathrm{L})$ to give a final substrate concentration of $0.5 \mathrm{~mm}$. Fluorescence was monitored in a Fluoroskan Ascent FL fluorescence microtitre plate reader from Thermo LabSystems at $25^{\circ} \mathrm{C}$, excitation/emission maxima $485 / 538 \mathrm{~nm}$, every 2 min over a $60 \mathrm{~min}$ period against appropriate controls. All assays were performed in triplicate. To determine the $\mathrm{pH}$ optimum, a range of overlapping buffer systems was used: acetate $(\mathrm{pH} 4-5.5)$, MES (2-morpholinoethanesulfonic acid; pH 5-7), HEPES [2-[4-(2hydroxyethyl)piperazin-1-yl]ethanesulfonic acid; $\mathrm{pH}$ 6-7.5] and bis-Tris propane ( $\mathrm{pH} 7-11)$. All buffers contained DTT and Brij35 at final assay concentrations of $5 \mathrm{~mm}$ and $0.1 \%(\mathrm{v} / \mathrm{v})$ respectively.

\subsection{Determination of digestive proteases by SDS-PAGE}

General gut proteolysis was also determined using gelatin PAGE, where total soluble protein $(10 \mu \mathrm{g})$ was run on a $12.5 \%$ SDSPAGE minigel copolymerised with $0.1 \%$ gelatin. Sample-loading buffer did not contain 2-mercaptoethanol, and samples were not boiled prior to loading. Subsequently, SDS was eluted from the gel following electrophoresis with $1 \%(\mathrm{v} / \mathrm{v})$ Triton X-100 in distilled water for $30 \mathrm{~min}$ at $4{ }^{\circ} \mathrm{C}$. The gel was cut into strips and incubated in $100 \mathrm{~mm}$ borate/ $\mathrm{NaOH}, \mathrm{pH} 8.0$, for $2 \mathrm{~h}$ at $37^{\circ} \mathrm{C}$ prior to staining in Kenacid Blue. 


\subsection{Enzyme inhibition studies}

Enzyme activity in the digestive tract of all C. carnea life stages was partially characterised using the class-specific protease inhibitors E-64, pepstatin A, EDTA and PMSF (final assay concentrations $10 \mu \mathrm{M}, 1 \mu \mathrm{M}, 10 \mathrm{~mm}$ and $1 \mathrm{~mm}$ respectively) and a range of synthetic and natural serine/cysteine protease inhibitors: TLCK, TPCK, chymostatin, elastatinal, CpTI, SBBI, rOC-1 and leupeptin (final assay concentrations $100 \mu \mathrm{M}, 100 \mu \mathrm{M}, 100 \mu \mathrm{M}, 100 \mu \mathrm{M}, 1.2 \mu \mathrm{M}$, $1,25 \mu \mathrm{M}, 1.2 \mu \mathrm{M}, 2 \mu \mathrm{M}$ and $100 \mu \mathrm{m}$ respectively). Inhibitors were preincubated with crude enzyme preparations at $25^{\circ} \mathrm{C}$ for $10 \mathrm{~min}$, prior to addition of the substrate. Using $\mathrm{pH}$ papers, the digestive tract of $C$. carnea was determined to be approximately $\mathrm{pH} 8$; all assays were carried out at $\mathrm{pH} 8$, using bis-Tris propane buffer, and performed in triplicate with appropriate controls. All buffers contained DTT and Brij35 at final assay concentrations of $5 \mathrm{~mm}$ and $0.1 \%(\mathrm{v} / \mathrm{v})$ respectively.

\subsection{Enzyme preparations for analysis of detoxifying en- zyme activity}

Enzyme extracts were prepared from adult C. carnea guts. Guts were removed, washed with distilled water, homogenised (10 guts $\mathrm{mL}^{-1}$ ) in ice-cold $0.1 \mathrm{M}$ potassium phosphate buffer $(\mathrm{pH} 7.2$, containing $1 \mathrm{~mm}$ EDTA, $1 \mathrm{~mm}$ DTT and $1 \mathrm{mM}$ PMSF) and centrifuged at $4{ }^{\circ} \mathrm{C}, 10000 \times \mathrm{g}$ for $20 \mathrm{~min}$. The supernatant was removed and quantified, and appropriate dilutions (for the tests below) were made using potassium phosphate buffer; preparations were assayed immediately for monoxygenase, glutathione $S$ transferase (GST) and esterase activity (EST), using a range of different substrates, as detailed below. All enzyme assays throughout were carried out in triplicate with appropriate controls. Assays for $O$-demethoxylation of $p$-nitroanisole (PNOD) and the O-deethoxylation of 7-ethoxycoumarin (ECOD) by cytochrome P450 monooxygenases were conducted using the procedures of Yang et al., ${ }^{49}$ Rose et al. ${ }^{50}$ and Ullrich and Weber. ${ }^{51}$ Non-specific esterase activity was measured with the substrate $\alpha$-naphthyl acetate $(\alpha-\mathrm{NA})$ at a final assay concentration of $1.9 \mathrm{~mm}$, following the method of Yang et al. ${ }^{49}$

The ability of $C$. carnea to hydrolyse the insecticide cypermethrin in vitro was determined by incubating cypermethrin in $5 \mu \mathrm{g} \mu \mathrm{L}^{-1}$ enzyme extract in a total volume of $250 \mu \mathrm{L}, 100 \mathrm{~mm}$ potassium phosphate buffer pH 7.2 (final substrate concentration $1 \mathrm{~mm}$ ). The reaction was terminated at time points of 15 and $45 \mathrm{~min}$ by the addition of $250 \mu \mathrm{L}$ of acetonitrile; the samples were centrifuged at $13000 \times g$ to pellet the precipitated protein, and $80 \mu \mathrm{L}$ of the supernatant was analysed by HPLC. A Kontron Instrument HPLC 430 detector and Kontron 460 autosampler were used with a mobile phase of $(\mathrm{A}) 1 \% \mathrm{H}_{3} \mathrm{PO}_{4}$ and (B) acetonitrile, stationary phase Phenomenex $250 \times 4.60 \mathrm{~mm}$ and a $5 \mu \mathrm{m} \mathrm{C18} \mathrm{100A} \mathrm{column.}$ The column was equilibrated in $65 \% \mathrm{~B}$, samples were injected and a gradient to $100 \%$ B was carried out over a 2 min period, with a flow rate of $1 \mathrm{~mL} \mathrm{~min}{ }^{-1}$. Eluate from the column was analysed for UV absorbance at $264 \mathrm{~nm}$.

\subsection{Statistical analysis}

Statistical analysis was carried out using one-way analysis of variance (ANOVA) (followed by mean separation via Tukey-Kramer tests) and two-tailed Student's $t$-tests. All tests were performed using Minitab v.14 software on an iMac computer. Differences between treatments were considered significant at the $P<0.05$ level. When data were not normally distributed, the nonparametric Kruskal-Wallis test replaced one-way ANOVA and the Mann-Whitney $U$-analysis replaced Student's $t$-test.
Table 1. Detection of OC-1 in Chrysoperla carnea frass collected after 17 days of feeding on artificial diet containing $1 \% \mathrm{w} / \mathrm{w}$ control OSR pollen (control), $1 \% \mathrm{w} / \mathrm{w}$ control OSR pollen $+1 \%$ rOC $-1 \mathrm{w} / \mathrm{w}(\mathrm{OC}-1$ control), $1 \% \mathrm{w} / \mathrm{w}$ control OSR pollen and cypermethrin (cypermethrin) and $1 \% \mathrm{w} / \mathrm{w}$ pollen from OC-1-expressing OSR (OC-1 pollen). Figures represent the mean ( \pm standard error) of three independent replicates from pooled insect samples

\begin{tabular}{lcc}
$\begin{array}{l}\text { Feeding } \\
\text { treatment group }\end{array}$ & $\begin{array}{r}\text { Total OC-1 detected } \\
\text { via ELISA }( \pm \text { SE) }(\mathrm{ng})\end{array}$ & $\begin{array}{c}\text { OC-1 detected (\% of total } \\
\text { soluble protein) }\end{array}$ \\
\hline Control & $0( \pm 0.02)$ & 0 \\
OC-1 control & $3.8( \pm 0.04)$ & 0.0019 \\
Cypermethrin & $0( \pm 0.01)$ & 0 \\
OC-1 pollen & $1.1( \pm 0.02)$ & 0.0005
\end{tabular}

\section{RESULTS}

\subsection{Production and purification of recombinant oryzacystatin-1 (rOC-1)}

Recombinant oryzacystatin was produced using Escherichia coli as the microbial expression system. Following purification by ionexchange and reverse-phase chromatography, the protein was visualised as a single band of $14 \mathrm{kDa}$ on SDS PAGE. Biological activity was confirmed by activity assay against papain, following the methods of Edmonds et al. ${ }^{40}$ (data not presented).

\subsection{Expression of OC-1 in pollen of transgenic OSR plants and detection in Chrysoperla carnea}

A standard curve was constructed from rOC-1 standards (0-10 ng) and the concentration of $\mathrm{OC}-1$ present in pollen extracts was calculated from the regression equation. An average of $0.4 \mathrm{ng} \mathrm{OC}$ 1 protein was detected from the $2 \mu \mathrm{g}$ of total soluble protein in pollen extracts, equating to an expression level of $0.02 \%$ OC- 1 in the transgenic pollen grains. Exposure of the predator to OC-1, either via OC-1-expressing pollen or artificial diet, was demonstrated in the frass by immunoassay (ELISA), where it was detected at a level of $0.001 \%$ in the experimental group fed purified $\mathrm{rOC}-1$ in artificial diet, while in the group fed transgenic OC-1-expressing pollen it was only present at $0.0005 \%$ of total soluble protein (Table 1 ).

Unfortunately, insufficient material was available to quantify the levels present in the digestive tract.

\subsection{Detection of cypermethrin in Chrysoperla carnea diges- tive tract tissue}

Cypermethrin was quantified in the digestive tracts of $C$. carnea that had been exposed to the insecticide via a diet containing pollen treated with the recommended field dose. The results demonstrated that cypermethrin could be readily detected, with a mean value of $0.16 \mu \mathrm{g} \mu \mathrm{L}^{-1}$, although these levels were highly variable (range $0.05-0.2 \mu \mathrm{g} \mu \mathrm{L}^{-1}$ ). No insecticide was detected in

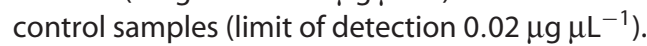

\subsection{Characterisation of gut digestive proteases of Chrysop- erla carnea}

Analysis of gelatin PAGE gels, visualising the major gut proteases of the different life stages of $C$. carnea, revealed differences in proteolytic enzymes between the different larval instars and adults. First-instar larvae revealed an unresolved area of digestive enzymes between 50 and $70 \mathrm{kDa}$, and one further major band of activity at approximately $37 \mathrm{kDa}$ (Fig. 1, L1), with trace levels of activity associated with two further lower-molecular-mass bands 


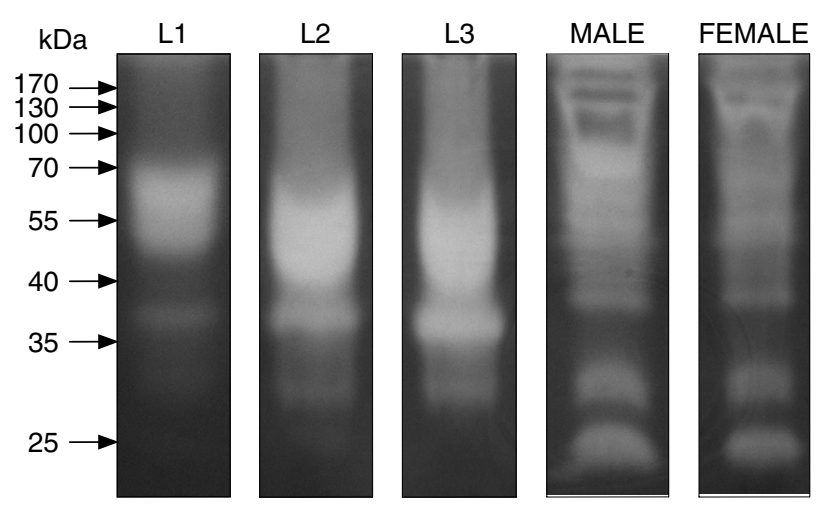

Figure 1. Digestive proteases from three different life stages of $C$. carnea. L1, first instar; L2, second instar; L3, third instar; Male, adult male; Female, adult female. Clear regions on the gel indicate gelatin hydrolysis at $\mathrm{pH} 8$.

(approximately 30 and $24 \mathrm{kDa}$ ). Second- and third-instar larvae again demonstrated the presence of unresolved protease activity, although this area included proteases as low as $40 \mathrm{kDa}$ in size. Similar banding patterns were also present in the later larval instars, although the level of activity appeared to increase with increasing instar, with the exception of the band of approximately $24 \mathrm{kDa}$ (Fig. 1).

The adult life stages showed no detectable differences in banding patterns between the two genders (Fig. 1), although metamorphosis did markedly alter the protease profile of C. carnea. Proteases capable of degrading gelatin were present, though unresolved, in the size range 100-55 kDa, with three major bands of activity detectable below this molecular mass. A band at approximately $39 \mathrm{kDa}$ appeared to be unique to the adult life stage, whereas the band at $37 \mathrm{kDa}$ present in the larval forms was absent. Bands present at $30 \mathrm{kDa}$ and $24 \mathrm{kDa}$ were present at significantly higher levels in adults than in the larvae, and appeared to be more prevalent in male C. carnea (Fig. 1).

Alteration of digestive proteases in the life cycle of the insect was reflected via changes in the $\mathrm{pH}$ profile of enzymes from the digestive tract. All three instars exhibited an optimal $\mathrm{pH}$ of 9.5 for the proteolysis of the protein substrate BODIPYL-FL casein; these results suggest a predominance of serine proteases in the digestive tract. A second peak of activity was also observed at lower $\mathrm{pH}$ (5.5-7.5), which is more indicative of cysteine proteolytic digestion (Fig. 2a). All larval instars showed very low levels of proteolytic activity compared with adults (Fig. 2b). While possessing different protease profiles, a broadly similar $\mathrm{pH}$ profile was observed for larvae and adults. Male lacewings, in particular, exhibited a pronounced pH optimum of between 8 and 9.5, with significant proteolytic activity present in both sexes at $\mathrm{pH}$ 6-11 (Fig. 2b).

The use of diagnostic classes of inhibitor confirmed that the digestive profile of adult $C$. carnea was dominated by serine proteases (Tables $2 a$ and b). Both the serine protease inhibitor PMSF and the proteinase inhibitor SBBI caused approximately $70 \%$ inhibition of proteolysis in both sexes; similarly, chymostatin was shown to cause a $64 \%$ and $69 \%$ inhibition of proteolysis in females and males respectively.

Inhibition by elastatinal ( $31 \%$ in males, $18 \%$ in females) suggested the presence of elastase-like enzymes, in addition to the dominant serine groups. The low levels of inhibition caused by the cysteine inhibitor E-64 suggested a low level of cysteine protease activity. This was confirmed with the use of leupeptin,
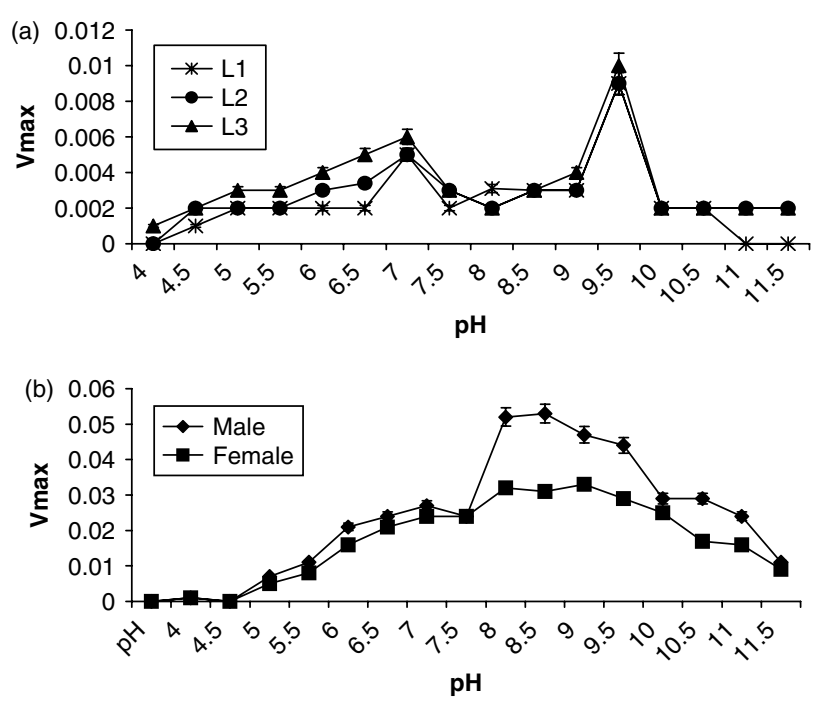

Figure 2. Determination of $\mathrm{pH}$ optima of digestive tract proteolysis in larval instars (a) and adults (b) of C. carnea, using the protein substrate BODIPY-FL casein. L1, first instar; L2, second instar; L3, third instar; Male, adult male; Female, adult female. Points and bars represent mean $\pm \mathrm{SE}$ for triplicate independent determinations.

Table 2a. Endogenous gut proteolytic activity of male Chrysoperla carnea following ingestion of an artificial diet containing: $1 \% \mathrm{w} / \mathrm{w}$ control OSR pollen (control), $1 \% \mathrm{w} / \mathrm{w}$ control OSR pollen $+1 \%$ rOC$1 \mathrm{w} / \mathrm{w}$ (OC-1 control), $1 \% \mathrm{w} / \mathrm{w}$ control OSR pollen and cypermethrin (cypermethrin) and $1 \% \mathrm{w} / \mathrm{w}$ pollen from OC-1-expressing OSR (OC-1 pollen). Protease activity was measured with BODIPYL-FL casein as substrate at $\mathrm{pH}$ 8. Figures represent the mean of three independent replicates carried out from pooled gut samples

\begin{tabular}{|lcccc|} 
& \multicolumn{4}{c|}{ Inhibition (\% relative to uninhibited control) } \\
\cline { 2 - 5 } Inhibitor $(\mu \mathrm{M})$ & Control & $\begin{array}{c}\text { OC-1 } \\
\text { control }\end{array}$ & Cypermethrin & $\begin{array}{c}\text { OC-1 } \\
\text { pollen }\end{array}$ \\
\hline PMSF (1000) & 71.9 & 58.3 & 75.0 & 76.7 \\
Chymostatin (10) & 68.7 & 55.6 & 66.7 & 70.0 \\
SBBI (2.5) & 68.7 & 83.3 & 66.7 & 63.3 \\
E-64 (10) & 6.2 & 33.4 & 6.2 & 10.7 \\
Pepstatin A (1) & 21.9 & 25.0 & 19.8 & 20.8 \\
Elastatinal (10) & 31.2 & 55.6 & 29.2 & 36.0 \\
Leupeptin (10) & 21.9 & 8.3 & 25.0 & 26.7 \\
EDTA(1000) & 25.0 & 22.2 & 22.9 & 26.7 \\
\hline
\end{tabular}

although male C. carnea showed greater inhibition with leupeptin than females. Male $C$. carnea also showed substantial inhibition with EDTA compared with females, suggesting a role for metallo proteases in the adult male digestive tract (Table 2). Pepstatin A showed a slight difference between the sexes. The increased effect of this inhibitor (14\% inhibition in females, $22 \%$ in males) in males may be linked to the greater intensity observed for gelatin digestion at $24 \mathrm{kDa}$ (Fig. 1).

All three larval instars showed a strong susceptibility to inhibition by serine protease inhibitors. PMSF caused almost $90 \%$ inhibition of proteolysis in first- (L1) and second-instar (L2) larvae, but its effects were reduced in third-instar (L3) insects (with a $1 \mathrm{~mm}$ concentration only causing $35 \%$ inhibition) (Fig. 3). Chymostatin, a specific inhibitor of chymotrypsin forms of serine proteases, caused $>80 \%$ inhibition in all larval instars; the dual trypsin/chymotryspin 
Table $\mathbf{2 b}$. Endogenous gut proteolytic activity of female Chrysoperla carnea following ingestion of an artificial diet containing: $1 \% \mathrm{w} / \mathrm{w}$ control OSR pollen (control), $1 \% \mathrm{w} / \mathrm{w}$ control OSR pollen $+1 \%$ rOC$1 \mathrm{w} / \mathrm{w}$ (OC-1 control), $1 \% \mathrm{w} / \mathrm{w}$ control OSR pollen and cypermethrin (cypermethrin) and $1 \% \mathrm{w} / \mathrm{w}$ pollen from OC-1-expressing OSR (OC-1 pollen). Protease activity was measured with BODIPYL-FL casein as substrate at $\mathrm{pH}$ 8. Figures represent the mean of three independent replicates carried out from pooled gut samples

\begin{tabular}{|lcccc|} 
& \multicolumn{4}{c|}{ Inhibition (\% relative to uninhibited controls) } \\
\cline { 2 - 5 } Inhibitor $(\mu \mathrm{M})$ & Control & $\begin{array}{c}\text { OC-1 } \\
\text { control }\end{array}$ & Cypermethrin & $\begin{array}{c}\text { OC-1 } \\
\text { pollen }\end{array}$ \\
\hline PMSF (1000) & 74.4 & 66.0 & 74.4 & 70.4 \\
Chymostatin (10) & 64.1 & 62.0 & 65.8 & 70.4 \\
SBBI (2.5) & 74.4 & 88.0 & 74.4 & 77.1 \\
E-64 (10) & 0 & 16.0 & 0 & 0 \\
Pepstatin A (1) & 14 & 7.7 & 4.3 & 14.8 \\
Elastatinal (10) & 17.9 & 32.0 & 17.9 & 29.6 \\
Leupeptin (10) & 7.7 & 22.0 & 9.4 & 11.1 \\
EDTA (1000) & 15.4 & 18.0 & 12.8 & 11.1 \\
\hline
\end{tabular}

inhibitor, SBBI, caused very similar effects. These results strongly suggest that both trypsin and chymotrypsin enzyme forms are prevalent in the serine-dominated digestive profile of $C$. carnea (Fig. 3). As indicated by the somewhat elevated activity around pH 7 (Fig. 2a), cysteine protease activity was expected to increase slightly in later instars, and, in line with this, E-64 caused 5\% inhibition in L1, $15 \%$ in L2 and $25 \%$ in L3, indicating relatively more cysteine protease activity in older instars. The inhibitor leupeptin, an inhibitor of both serine and cysteine proteases, on the other hand, caused a 51\% decrease in activity in first-instar larvae, a 29\% decrease in activity in second-instar larvae, but negligible effects upon third-instar larvae (Fig. 3). Similarly, EDTA, an inhibitor of metallo proteases, caused negligible inhibition in the final larval instar, but $62 \%$ in L1 and $36 \%$ in L2; this suggests the presence of metallo proteases early in the life cycle of C. carnea. Pepstatin A had no discernable effect upon proteolysis in any instar (data not shown).

\subsection{Effects of rOC-1 in artificial diet on Chrysoperla carnea 3.5.1 Effects on life history parameters}

When fed at $1 \% \mathrm{w} / \mathrm{w}$ on artificial diet, the cysteine protease inhibitor OC-1 had no significant impact on the mortality of adult C. carnea, with $98 \%$ survival during the 17 day trial. Evidence that adults not only were exposed to the inhibitor but consumed

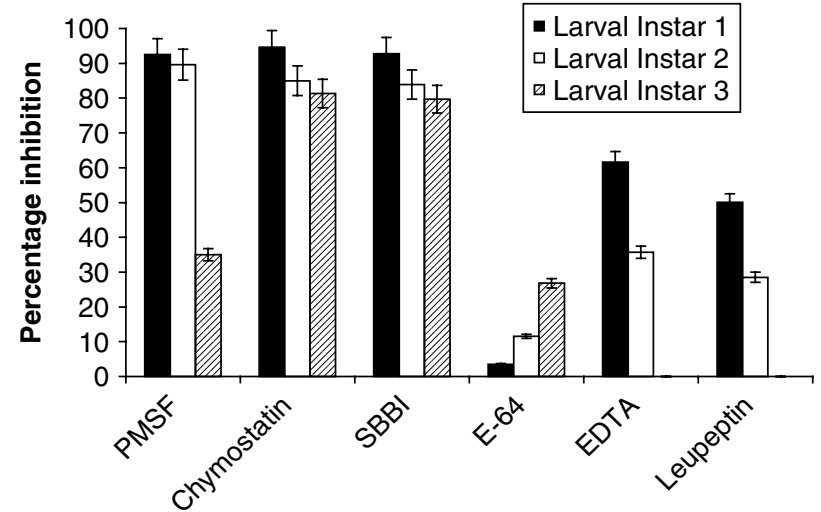

Figure 3. Percentage inhibition of digestive proteases in larval stages of C. carnea. Bars represent mean \pm SE for triplicate independent determinations.

it was confirmed by immunoassay, which clearly demonstrated the presence of $\mathrm{rOC}-1$ in the frass (Table 1). Treatment with the purified cysteine protease inhibitor did, however, significantly reduce the number of eggs laid throughout the trial $(\mathrm{df}=3,88$, $F=29.25, P=0.002$ ) (Table 3 ). Although six females fed $\mathrm{rOC}-1$ did not produce eggs during this period, a figure comparable with that of the control group, females that did produce eggs laid an average of ca 20 fewer eggs female ${ }^{-1}$ throughout the 17 day period (Tukey-Kramer test $P=0.002$ ) (Table 3). This reduction in egg production was linked to a significant delay $(W=790, \mathrm{df}=1$, $P=0.035)$ in the onset of egg production by female $C$. carnea by comparison with control females (Fig. 4). Once egg production had commenced, however, females feeding on rOC-1 laid at a rate comparable with that of the control females. Fecundity was also assessed, in terms of egg viability (Table 3). Eggs produced from females fed on a $1 \% \mathrm{w} / \mathrm{w}$ rOC-1 diet showed a level of hatching success $(79.7 \%)$ equal to that of control C. carnea eggs, thus demonstrating that the inhibitor did not directly affect hatching success; however, over the limited trial period, fecundity was reduced as a consequence of a delay in the onset of oviposition.

\subsubsection{Effects on endogenous gut proteases}

The effects of OC-1 on digestive proteases of instars and adult $C$. carnea were investigated in vitro (Fig. 5). The cysteine protease inhibitor had a strong effect on proteases of first-instar (L1) C. carnea, causing almost $50 \%$ inhibition of protease activity (at a concentration of $5 \mu \mathrm{M})$. However, the later larval instars were less

Table 3. Egg production and egg hatching success of Chrysoperla carnea following ingestion of artificial diet containing: $1 \% \mathrm{w} / \mathrm{w}$ control OSR pollen (control), $1 \% \mathrm{w} / \mathrm{w}$ control OSR pollen $+1 \% \mathrm{rOC}-1 \mathrm{w} / \mathrm{w}$ (OC-1 control), $1 \% \mathrm{w} / \mathrm{w}$ control OSR pollen and cypermethrin (cypermethrin) and $1 \% \mathrm{w} / \mathrm{w}$ pollen from OC-1-expressing OSR (OC-1 pollen). The numbers of eggs produced per female from the different treatments were submitted to one-way ANOVA, while pre-oviposition periods and hatching success were analysed by Mann-Whitney $U$-tests. In all cases, values followed by different letters are significantly different $(P<0.05)$

\begin{tabular}{|lcccccc} 
Treatment group & $\begin{array}{c}\text { Number of } \\
\text { fertile } \\
\text { females }\end{array}$ & $\begin{array}{c}\text { Number of } \\
\text { non-laying } \\
\text { females }\end{array}$ & $\begin{array}{c}\text { Median day } \\
\text { females commenced } \\
\text { oviposition }\end{array}$ & $\begin{array}{c}\text { Total number of } \\
\text { eggs laid by day 17 }\end{array}$ & $\begin{array}{c}\text { Mean number of } \\
\text { eggs laid per female } \\
( \pm \text { SE) }\end{array}$ & $\begin{array}{c}\text { Overall \% hatching success } \\
\text { ( } \pm \text { SE) from surviving } \\
\text { insects on day 17 of } \\
\text { the trial }\end{array}$ \\
\hline Control & 30 & 5 & $8.5 \mathrm{a}$ & 1912 & $63.7( \pm 19) \mathrm{a}$ & $80.0( \pm 2.1) \mathrm{b}$ \\
OC-1 control & 29 & 6 & $11.0 \mathrm{~b}$ & 1276 & $44.0( \pm 15) \mathrm{b}$ & $79.7( \pm 2.2) \mathrm{b}$ \\
Cypermethrin & 27 & 8 & $12.0 \mathrm{c}$ & 750 & $27.7( \pm 14) \mathrm{c}$ & $75.6( \pm 3.6) \mathrm{a}$ \\
OC-1 pollen & 31 & 4 & $8.0 \mathrm{a}$ & 2073 & $66.8( \pm 19) \mathrm{a}$ & $80.9( \pm 2.6) \mathrm{b}$ \\
\hline
\end{tabular}




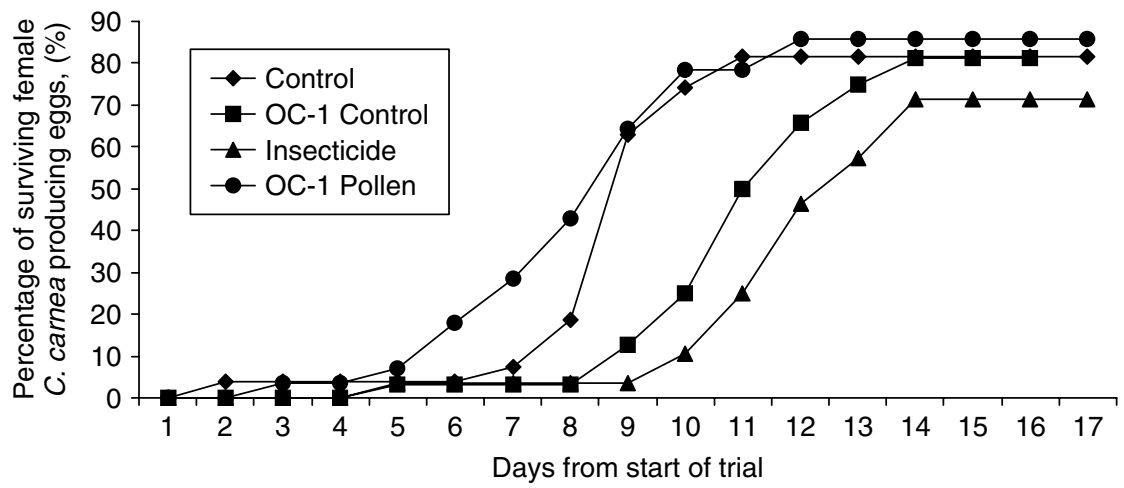

Figure 4. Percentage of surviving paired female $C$. carnea producing eggs, fed on artificial diet containing: $1 \% \mathrm{w} / \mathrm{w}$ control OSR pollen (control), $1 \% \mathrm{w} / \mathrm{w}$ control OSR pollen + 1\% rOC-1 w/w (OC-1 control), $1 \% \mathrm{w} / \mathrm{w}$ control OSR pollen and cypermethrin (insecticide) and $1 \% \mathrm{w} / \mathrm{w}$ pollen from OC- 1 -expressing OSR (OC-1 pollen). $N=35$.

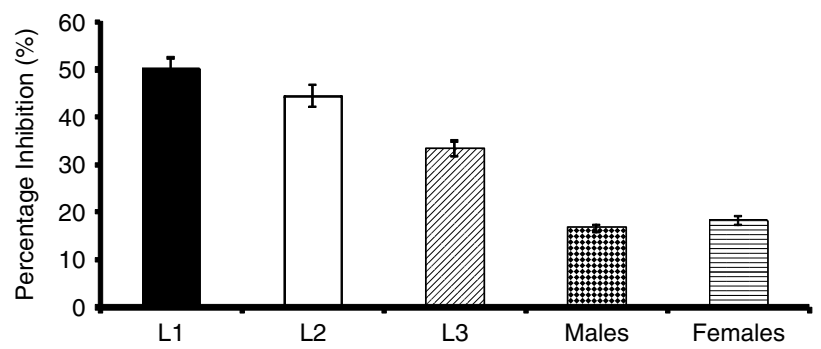

Figure 5. Relative susceptibility of digestive tract enzyme extracts from the different life stages of $C$. carnea to inhibition by the cysteine protease inhibitor oryzacystatin-1 (OC-1; $5 \mu \mathrm{M})$ in vitro. L1, first instar; L2, second instar; L3, third instar. Activity was measured using the proteolytic substrate BODIPY-FL casein, $\mathrm{pH}$ 8. Bars represent mean $\pm \mathrm{SE}$ for triplicate independent determinations.

susceptible to inhibition, decreasing to 40 and $30 \%$ in second(L2) and third-instar (L3) larvae respectively. These results are in contrast to predicted results, as cysteine proteolytic activity was seen to increase slightly at a lower $\mathrm{pH}$ with larval age, but, more importantly, the cysteine inhibitor E-64 was a more potent inhibitor in the older larvae (Fig. 3), indicating relatively greater cysteine protease activity. Both sexes of adult $C$. carnea showed only $10 \%$ inhibition (in vitro) to OC- 1 ; this is consistent with results demonstrating a limited effect of the cysteine inhibitor E-64 on adult digestive proteases (Tables $2 \mathrm{a}$ and $\mathrm{b}$ ).

Although consumption of OC-1 by $C$. carnea adults did not appear to alter the protease profile as visualised by gelatin PAGE (data not shown), the presence of the inhibitor caused a change in the relative activities of the protease forms present in the digestive tract (Tables $2 \mathrm{a}$ and b). Male C. carnea showed a decrease in sensitivity to inhibition by PMSF and chymostatin, indicating an increase in serine and particularly chymotrypsin proteases in response to feeding on $\mathrm{rOC}-1$, while SBBI caused a greater inhibitory effect, indicating a switch away from trypsin proteases. Feeding on rOC-1 at $1 \% \mathrm{w} / \mathrm{w}$ also caused increased sensitivity to inhibition by both E-64 and elastatinal (by approximately $30 \%$ and $24 \%$, respectively, compared with the controls), but pepstatin A, an inhibitor of aspartic proteases, showed almost identical levels of inhibition to that in control male adult lacewings (Table 2a).

Similar trends, though less pronounced, were observed in female lacewings, following consumption of $\mathrm{rOC}-1$, with the exception of pepstatin A, which caused a slight (6\%) increase in sensitivity to inhibition compared with the control-fed adults (Table 2b).

\subsection{Effects of pollen from transgenic OC-1-expressing OSR on Chrysoperla carnea}

3.6.1 Effects on life history parameters

Adult C. carnea showed no detrimental effects in any of the life history parameters measured as a consequence of feeding on pollen from OC-1-expressing OSR (Table 3). ELISA results (Table 1) demonstrated that the adults were exposed to and ingested $\mathrm{OC}-1$; however, this level of exposure caused no significant impact on lacewing survival compared with that of the control group (data not presented). Furthermore, the presence of OC-1-expressing pollen in the diet caused no detrimental effects on C. carnea fecundity. In this experimental group, only four pairs failed to produce eggs during the 17 day trial period, with females laying 66.8 eggs female ${ }^{-1}$, which is similar to the control rate of 63.7 eggs female f $^{-1}$ (Table 3 ). This figure was significantly higher than the oviposition rate of $C$. carnea fed with insecticide or purified rOC-1-treated diet $(t=5.8, \mathrm{df}=25, P=0.002$ and $t=1.84$, df $=33, P=0.04$ respectively).

Interestingly, females fed transgenic pollen at $1 \% \mathrm{w} / \mathrm{w}$ in the diet commenced oviposition before any of the other groups (Fig. 4), with the first females ovipositing just 5 days after mating. Feeding on the transgenic (OC-1-containing) pollen also had no detrimental impact on egg viability, with around $80 \%$ of eggs hatching, irrespective of treatment. Hatch rates of eggs derived from the OC-1 treatments were significantly higher than for those of cypermethrin-exposed insects $(W=321, \mathrm{df}=1, P=0.001)$ (Table 3).

\subsubsection{Effects on endogenous gut proteases and enzymes involved} in detoxification

Results from inhibition studies demonstrated that OC- 1 was a weak inhibitor of adult lacewing digestive proteases in vitro (Fig. 5), and that, when the purified inhibitor was ingested, the predator responded by an alteration in levels of different protease classes (Tables 2a and b; Section 3.5.2). However, when adults were fed on a diet containing $1 \%$ transgenic pollen, very few changes were observed in the digestive protease profile (Tables 2a and b). Female C. carnea showed a slight increase in inhibition by elastatinal, a response clearly discernable when they were fed the purified protein; males also showed a slight increase in susceptibility to this inhibitor. 
Table 4. Activity of Chrysoperla carnea digestive tract crude enzyme extract against substrates specific for P450, GST and esterase (EST) activity following ingestion of artificial diet containing: $1 \% \mathrm{w} / \mathrm{w}$ control OSR pollen (control), $1 \% \mathrm{w} / \mathrm{w}$ control OSR pollen $+1 \% \mathrm{rOC}-1 \mathrm{w} / \mathrm{w}$ (OC-1 control), $1 \% \mathrm{w} / \mathrm{w}$ control OSR pollen and cypermethrin. Insecticide and $1 \% \mathrm{w} / \mathrm{w}$ pollen from OC-1-expressing OSR (OC-1 pollen). Assays measured the O-demethooxylation of $p$-nitroanisole (PNOD), the O-deethoxylation of 7-ethoxycoumarin (ECOD) and the breakdown of 1-chloro-2,4-dinitrobenzene (CBND) and $\alpha$-naphthyl acetate $(\alpha-\mathrm{NA})$. Figures represent the mean of three independent replicates carried out from three pooled insect samples per treatment

\begin{tabular}{|c|c|c|c|c|}
\hline \multirow[b]{2}{*}{$\begin{array}{l}\text { Treatment } \\
\text { group }\end{array}$} & \multicolumn{2}{|c|}{ P450 assay } & \multirow{2}{*}{ 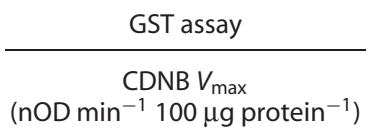 } & \multirow{2}{*}{$\begin{array}{c}\text { EST assay } \\
\frac{\alpha-\mathrm{NA} V_{\max }}{\left(\text { nOD } \min ^{-1} 100 \mu \mathrm{g} \text { protein }^{-1}\right)}\end{array}$} \\
\hline & $\begin{array}{c}\text { PNOD } V_{\max } \\
\left(\text { nOD } \text { min }^{-1} 100 \mu \mathrm{g} \text { protein }\right. \\
\end{array}$ & $\begin{array}{c}\text { ECOD } V_{\max } \\
\left(\text { nOD } \text { min }^{-1} 100 \mu \mathrm{g} \text { protein }{ }^{-1}\right)\end{array}$ & & \\
\hline Control & 0.03 & 0.05 & 0.26 & 21.45 \\
\hline OC-1 control & 0.01 & 0.03 & 0.42 & 24.3 \\
\hline Cypermethrin & 0.04 & 0.04 & 0.51 & 33.64 \\
\hline OC-1 pollen & 0.04 & 0.02 & 0.32 & 26.32 \\
\hline
\end{tabular}

Enzyme assays with synthetic substrates for P450s and GSTs exhibited only minimal levels of activity, which were not appreciably affected by consumption of OC-1-expressing pollen (Table 4). The level of non-specific EST activity, on the other hand, was high $\left(V_{\max }=26.32 \mathrm{nOD} \min ^{-1} 100 \mu \mathrm{g}_{\text {protein }}{ }^{-1}\right)$, although the presence of the transgenic pollen in the diet caused a further slight (but not significant, $P=0.076$ ) increase in activity.

\subsection{Effects of cypermethrin on Chrysoperla carnea}

\subsubsection{Effects on life history parameters}

Cypermethrin fed at a 100 -fold dilution of the recommended field application dosage as part of a standard artificial diet caused no significant mortality in adult C. carnea, with $98 \%$ survival over the 17 day trial period. When fed in this dilution, the insecticide could clearly be detected, at an average level of $0.16 \mu \mathrm{g} \mu \mathrm{L}^{-1}$. However, this sublethal level of exposure to cypermethrin did have a significant effect on insect fecundity ( $d f=3,88, F=29.25$, $P=0.0001$ ), with eight females laying no eggs (Table 3 ), the lowest recorded number of eggs laid for any treatment group. Females that did produce eggs laid significantly fewer eggs (just 35.7 on average) than either control-fed females (Tukey-Kramer $P=0.001$ ) or any other experimental group (Tukey-Kramer $P=0.022$ for OC-1 control and Tukey-Kramer $P=0.0002$ for OC1 pollen) (Table 3). The insecticide-treated group also exhibited the greatest delay in the onset of oviposition (Fig. 4), this being significantly greater compared with either the control-fed group or the group fed transgenic pollen $(W=662$, df $=1, P=0.02$ and $W=263, \mathrm{df}=1, P=0.03$ respectively). Egg viability was also significantly reduced in the insecticide-fed group compared with the control, the OC- 1 control and the OC-1 pollen $(W=616,321$ and 744 respectively, $\mathrm{df}=1$ and $P<0.05$ in all cases) (Table 3 ).

\subsubsection{Effects on endogenous gut proteases and enzymes involved in detoxification}

Feeding on cypermethrin caused no significant changes in the digestive protease profile of adult C. carnea. Gelatin PAGE did not reveal the presence of any novel forms of protease (data not shown), and analysis with diagnostic inhibitors showed no alterations in the levels of protease forms present in adult C. carnea of either sex (Tables 2a and b).

HPLC analysis of cypermethrin digests (Fig.6) exposed for different time periods to $C$. carnea digestive tract enzyme preparations in vitro clearly demonstrated that insects with no previous contact with the insecticide were capable of rapidly degrading (within $15 \mathrm{~min}$ ) $1 \mathrm{~mm}$ cypermethrin. Exposure of adults
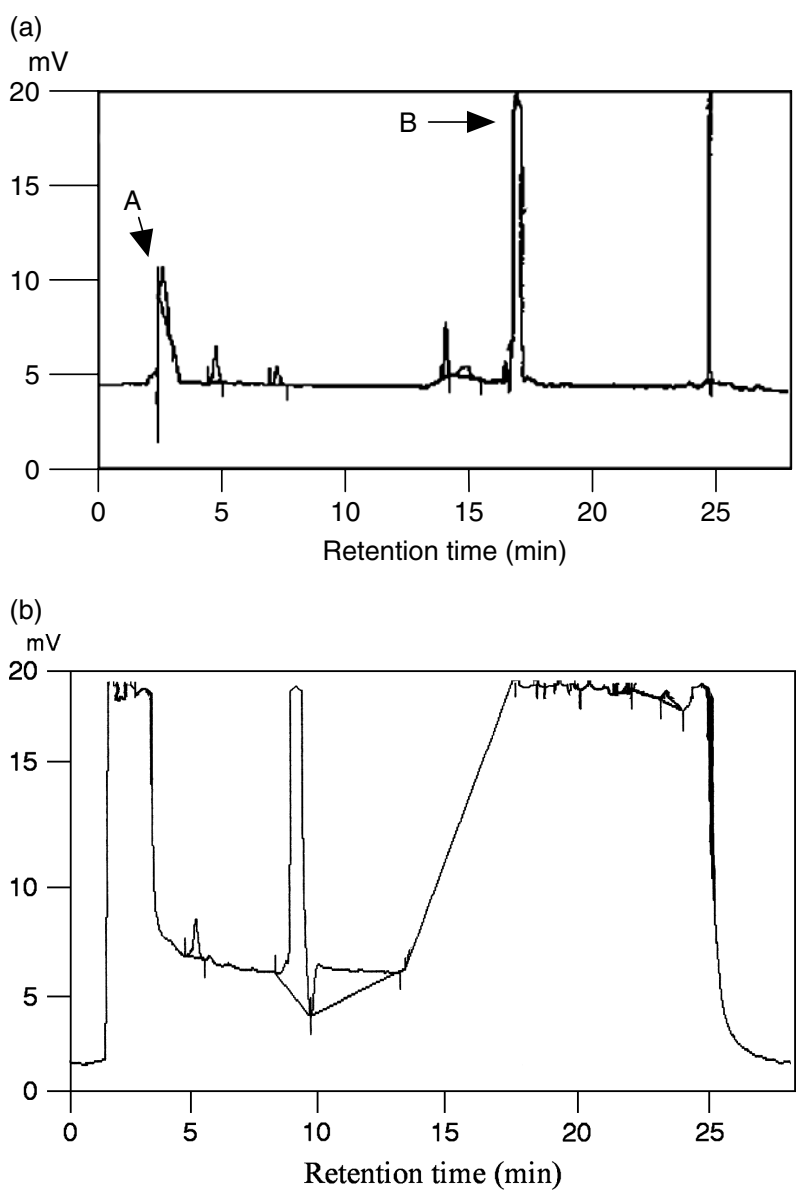

Figure 6. (a) Chromatograph obtained from $1 \mathrm{mM}$ cypermethrin in DMSO. Mobile phase $1 \% \mathrm{H}_{3} \mathrm{PO}_{4}$ and $0-100 \%$ acetonitrile gradient. A represents the retention time of DMSO and $\mathbf{B}$ the retention time of cypermethrin. (b) Chromatograph obtained from incubation of protein samples obtained from C. carnea feeding on artificial diet (no insecticide) incubated for $15 \mathrm{~min}$ with $1 \mathrm{mM}$ cypermethrin. Peaks represent the breakdown products of cypermethrin. Mobile phase $1 \% \mathrm{H}_{3} \mathrm{PO}_{4}$ and $0-100 \%$ acetonitrile gradient.

to the insecticide when fed caused no alteration in this response, as the enzymes remained capable of rapidly degrading the insecticide in vitro, so producing a variety of digestion products (Fig. 6). The addition of NADPH caused no alteration in either the pattern of breakdown products or the rate of breakdown, suggesting a limited role of P450 activity in insecticide degradation. 
Preliminary enzyme assays were carried out with synthetic substrates for P450s, GSTs and ESTs. While PNOD, ECOD (P450 substrate) and CDND (GST substrate) were hydrolysed at a negligible rate (Table 4), $\alpha$-NA, the substrate for non-specific EST activity, was degraded rapidly $\left(\mathrm{V}_{\max }=21.45 \mathrm{nOD} \mathrm{min}^{-1} 100 \mu \mathrm{g}\right.$ protein $^{-1}$ ) in both control samples (no exposure to insecticide) and all experimental groups (the rate was highest, though not significantly so, in the insecticide fed group). This may suggest that ESTs play a key role in the insect's ability to degrade insecticides.

\section{DISCUSSION}

\subsection{Characterisation of major digestive proteases in the gut of Chrysoperla carnea}

The use of synthetic substrates and diagnostic inhibitors suggests that serine proteolytic enzymes dominate the digestive tract of C. carnea, with both trypsin and chymotrypsin being present at high levels in the larvae and adults. In adults, approximately $80 \%$ of the protease activity was shown to be susceptible to inhibition by serine protease inhibitors, with the remaining activity being attributed to metallo or cysteine proteases. Furthermore, gelatin PAGE analysis revealed the presence of a protease $(37 \mathrm{kDa})$ that increased in activity with each subsequent instar; the evidence suggests that this is most likely a further serine protease. Across both adult and larval instars the digestive tract of $C$. carnea is dominated by serine proteases, with large changes seen in the levels of the different protease forms throughout the life cycle. First-instar larvae show higher levels of sensitivity to inhibition by metallo and leupeptin inhibitors compared with the later stages, with the converse being the case for cysteine protease inhibitors. Cysteine proteases, on the other hand, were shown to play a limited role in protein digestion, with levels of proteases sensitive to inhibition by the cysteine protease inhibitor E-64 being negligible in first-instar larvae, increasing to approximately $30 \%$ of the total proteolytic activity in third instars and declining to just $10 \%$ in the adult. To date, relatively few studies have been carried out to characterise the digestive enzymes present in the order Neuroptera, and in particular C. carnea. Data provided in the present study support earlier findings by Ferran et al. ${ }^{52}$ and Yazlovetsky, ${ }^{53}$ who demonstrated the dominance of trypsin and chymotrypsin forms of proteases present in the larvae of this predator. More recently, Mochizuki ${ }^{43}$ suggested that neuropteran insects have codominance of serine and cysteine protease forms; however, the present study does not support this hypothesis.

Male and female C. carnea show a remarkable similarity in their digestive protease profile, with an increase in activity of pepstatin A-susceptible proteases in males being the only discernable difference. To the authors' knowledge, this study is the most detailed analysis of digestive proteases to have been carried out on C. carnea. Ferran et al. ${ }^{52}$ showed changes in some forms of amino-peptidases throughout the life cycle of this predator, while Ermicheva et al. ${ }^{54}$ investigated overall proteolytic activity through post-embryo development; however, no previous studies have identified the specific types of protease present in the gut. In contrast to the present study, many studies carried out with different insect species have reported expression of similar types of protease activity throughout the life cycle of insects.

Previous studies had suggested that both serine and cysteine proteases may play a role in protein digestion in C. carnea, and, on the basis of these studies, the cysteine protease inhibitor,
OC-1, and oilseed rape expressing this inhibitor were selected to investigate potential effects of transgenic crops on this important predatory species. However, results from this study demonstrated the predominance of serine proteases within the digestive tract, with only $10 \%$ of the adult gut digestive proteolytic activity being inhibited by OC-1. As anticipated, feeding purified rOC1 in artificial diet at $1 \% \mathrm{w} / \mathrm{w}$ caused no major alteration to digestive physiology. Neither did it stimulate production of novel sensitive or insensitive proteases. However, there was a subtle shift in the proteolytic profile, with an increase in serine forms, especially of chymotrypsin, although there was a reduction in elastase activity. The lacewing also responded by producing increased levels of aspartic proteases. The ability of phytophagous insects to respond to the presence of dietary inhibitors by modulation of the protease profile has been well documented. ${ }^{33,34}$ More recently, Ferry et al. ${ }^{55}$ demonstrated that the beneficial predator Harmonia axyridis (Pallas), when exposed to OC-1-expressing OSR via a tritrophic interaction, was able to respond by the upregulation of native proteases, while the carabid Pterostichus madidus (Fabricius) responded to MTI-2-expressing plants by switching from predominantly trypsin to predominantly chymotrypsin. ${ }^{42}$

\subsection{Effects of the cysteine protease inhibitor OC-1 on Chrysoperla carnea}

While in vitro studies would suggest a limited impact of OC-1 on C. carnea, and the feeding of $\mathrm{rOC}-1$ in the diet at $1 \% \mathrm{w} / \mathrm{w}$ caused no negative impact on survival, the fecundity of the beneficial insect was reduced. There was both a significant delay (three days) in oviposition and in the total numbers of eggs laid over the 17 day trial. A reduction in fecundity has previously been noted with protease inhibitors, and in particular with OC-1 for other arthropods. ${ }^{56-58}$ However, in these cases a much greater impact on digestive proteases, nutrient availability and consequently development was linked to the decrease in fecundity. Furthermore, Rahbe et al. ${ }^{59}$ also demonstrated a decrease in aphid survival in the presence of the Bowman-Birk inhibitor which targets both trypsin and chymotrypsin.

Analysis of the levels of OC- 1 detected in the frass of adult C. carnea showed that predators exposed to the transgenic pollen had only $25 \%$ of the level of inhibitor compared with those consuming the diet containing the rOC-1. Feeding OC1-expressing pollen caused no significant negative impact on digestive proteases, mortality or fecundity. To the authors' knowledge, no other studies have been carried out to investigate the potential impact of transgenic OSR pollen on adult C. carnea. Nevertheless, the purified recombinant OC-1 did cause limited effects on protein digestion and fecundity, demonstrating a potential for toxicity.

To date, a wide variety of protease inhibitors have been expressed in crop plants. ${ }^{60}$ Thus, given the potential for rOC-1 to affect lacewing fecundity, it is important that other protease inhibitors, particularly those targeted to the serine-dominated C. carnea digestive tract, be evaluated for potential negative effects. Interestingly, a study by Lawo and Romeis ${ }^{24}$ revealed no detrimental effect on important life-table parameters of $C$. carnea larvae when directly fed with SBTI at a dose of $1 \%$ $\mathrm{w} / \mathrm{v}$ in a sucrose solution. As control strategies based on the expression of a combination of different protease inhibitors are being investigated, it is important that the effects of such combinations be evaluated more thoroughly on beneficial insects. 


\subsection{Effects of the pyrethroid cypermethrin on Chrysoperla carnea}

One of the major objectives of the present study was to compare the effects of recombinant DNA technology with the use of synthetic insecticides for insect pest control on beneficial insects. The insecticide utilised in this study was the pyrethroid cypermethrin. Results obtained clearly demonstrate that this insecticide exhibited more deleterious effects on C. carnea than either the transgenic OC-1-expressing pollen or the purified rOC-1. While the insecticide exhibited little effect on mortality, fecundity (rate of egg production) and fertility (hatching success) were significantly reduced. Chrysoperla carnea adults were able to tolerate cypermethrin in the digestive tract at $0.16 \mu \mathrm{g} \mu \mathrm{L}^{-1}$, presumably as a consequence of rapid degradation of the compound owing to the increased levels of non-specific esterase (EST) activity that were observed. Similar findings were reported by Ishaaya and Casida ${ }^{12}$ for $C$. carnea larvae in response to exposure to the insecticide permethrin. While this increase in activity appeared to protect mature lacewings from mortality, it did not prevent a significant reduction in fecundity. In the present study, insecticide-fed females laid the lowest number of eggs throughout the 17 day trial, with subsequent hatching success in this group being significantly lower than either the control or transgenic pollen-fed groups; however, fertility, and in particular fecundity, remained high (74\%), even in cypermethrin-treated insects. Determination of the significance of such a reduction in fecundity on active field populations of the chrysopid would be essential for a thorough evaluation of the environmental impact of synthetic pyrethroids. Although the trial was terminated before the completion of the reproductive cycle of $C$. carnea, feeding on a diet containing purified OC-1 $(1 \% \mathrm{w} / \mathrm{w})$ did delay the onset of egg production; however, subsequent fecundity rates and fertility were the same as for the control. It would be interesting to determine whether ingestion of a serine protease inhibitor, which more effectively targets the digestive proteases of the predator, would have caused more deleterious effects. At day 17 of the trial, insecticide-fed C. carnea produced eggs at a significantly lower rate than in all three other feeding treatments; further trials are needed to establish the effects on fecundity throughout the adult female life stage.

Few studies have investigated the effects of feeding cypermethrin-contaminated food to adult C. carnea. Studies by Ishaaya and Casida ${ }^{12}$ estimate the $\mathrm{LD}_{50}$ of this insecticide in larval C. carnea to be $17 \mu \mathrm{g} \mu \mathrm{L}^{-1}$ when applied topically, although Rumpf et al. ${ }^{61}$ demonstrated that topical doses of $2.4 \mu \mathrm{g} \mu \mathrm{L}^{-1}$ caused no impact on survival of larval C. carnea. In contrast to results presented here, where continuous exposure to cypermethrin at $19 \mu \mathrm{m}$ in artificial diet caused sublethal effects, work by Grafton-Cardwell and Hoy ${ }^{62}$ reported no significant reduction in either survival or fecundity when the two pyrethroids permethrin and fenvalerate were applied at recommended field rates to C. carnea. Work by Hassan et al. ${ }^{63}$ is the only study to show a direct effect of pyrethroids (permethrin and fenvalerate) on C. carnea, although effects on larval mortality were analysed in conjunction with adult fecundity and it is thus difficult to determine which stage was affected.

While this study has demonstrated the potential for pest management to impact on predators, more importantly it highlights the ability of the predator to detoxify/respond to two diverse treatments. In this case, exposure to the insecticide carried a greater fitness cost (in terms of impact on fecundity) than exposure to a PI expressed in transgenic crops.

\section{ACKNOWLEDGEMENTS}

The authors would like to thank the Yorkshire Agricultural Society for financial support. EAM gratefully acknowledges receipt of an NERC studentship (NER/S/A/2002/10523). EAM would also like to express his gratitude to all the staff at Agroscope ART for help offered.

\section{REFERENCES}

1 McEwen PK, New TR and Whittington AE, Lacewings in the Crop Environment. Cambridge University Press, Cambridge, UK (2001).

2 Jacas JA and Vinuela E, Analysis of a laboratory method to test the effects of pesticides on adult females of Opius concolor (Hym., Braconidae), a parasitoid of the olive fruit fly, Bactrocera oleae (Dip., Tephritidae). Biocontrol Sci Tech 4:147-154 (1994).

3 Li Y, Meissle M and Romeis J, Consumption of Bt maize pollen expressing $\mathrm{Cry} 1 \mathrm{Ab}$ or $\mathrm{Cry} 3 \mathrm{Bb} 1$ does not harm adult green lacewings, Chrysoperla carnea (Neuroptera: Chrysopidae). PLOS ONE e2909 (2008).

4 Young YN, Seo MJ, Shin JG, Jang C and Yu YM, Toxicity of greenhouse pesticides to multicoloured Asian lady beetles, Harmonia axyridis (Coleoptera: Coccinellidae). Biol Cont 28:164-170 (2003).

5 Schaub L, Garnier G and Bloesch B, An extended laboratory method maximising plant contact time to study the side-effects of pesticides on plant dwelling predators. J Appl Entomol 126:155-159 (2002).

6 Stapel JO, Cortecero AM and Lewis WJ, Disruptive sublethal effects on insecticides on biological control: altered foraging ability and life span of a parasitoid after feeding on extrafloral nectar of cotton treated with systemic insecticides. Biol Cont 17:243-249 (2000).

7 Chang CP and Plapp FW, DDT and synthetic pyrethroids: mode of action, selectivity, and mechanism of synergism in the tobacco budworm (Lepidoptera: Noctuidae) and a predator, Chrysopa carnea Stephens (Neuroptera: Chrysopidae). J Econ Entomol 76:1206-1210 (1983).

8 Huerta A, Madina P, Castañera P and Viñuela E, Laboratory studies with Trichilia havenensis, a botanical pesticide and adults of Chrysoperla carnea. IOBC/WPRS Bulletin 26:25-32 (2003).

9 Schmuck R, Mager H, Kunast CH, Bock KD and Storck-Weyermuller S, Variability in the reproductive performance of beneficial insects in standard laboratory toxicity assays - implications for hazard classification of pesticides. Ann Appl Biol 128:437-451 (1996).

10 Medina P, Budia F, Del Estal P and Viñuela E, Influence of azadirachtin, a botanical insecticide, on Chrysoperla carnea (Stephens) reproduction: toxicity and ultrastructural approach. J Econ Entomol 97:43-50 (2004).

11 Plapp FW and Bull DL, Toxicity and selectivity of some insecticides to Chrysopa carnea, a predator of the tobacco budworm. Environ Entomol 7:431-434 (1978).

12 Ishaaya I and Casida JE, Pyrethroid esterase(s) may contribute to natural pyrethroid tolerance of larvae of the common green lacewing. Environ Entomol 10:681-684 (1981).

13 Ishaaya I, Insect detoxifying enzymes: their importance in pesticide synergism and resistance. Arch Insect Biochem Physiol 22:263-276 (1993).

14 James C, Global status of commercialized biotech/GM crops: 2008. ISAAA Brief No. 39, International Service for the Acquisition of Agri-Biotech Applications, Ithaca, NY (2007).

15 Romeis J, Meissle M and Bigler F, Transgenic crops expressing Bacillus thuringiensis toxins and biological control. Nature Biotechnol 24:63-71 (2006).

16 Wolfenbarger LL, Naranjo SE, Lundgren JG, Bitzer RJ and Watrud LS, Bt crop effects on functional guilds of non-target arthropods: a meta-analysis. PLoS ONE 3:e2118 (2008).

17 Dutton A, Klein H, Romeis J and Bigler F, Uptake of Bt-toxin by herbivores feeding upon transgenic maize and consequences for the predator Chrysoperla carnea. Ecol Entomol 27:441 -447 (2002).

18 Dutton A, Klein H, Romeis J and Bigler F, Prey-mediated effects of Bacillus thuringiensis spray on the predator Chrysoperla carnea in maize. Biol Cont 26:209-215 (2003).

19 Hilbeck A, Baumgartner M, Fried P and Bigler F, Effects of transgenic Bacillus thuringiensis corn-fed prey on mortality and development time of immature Chrysoperla carnea (Neuroptera: Chrysopidae). Environ Entomol 27:480-487 (1998). 
20 Hilbeck A, Moar WJ, Pusztai-Carey M, Filippini A and Bigler F, Toxicity of Bacillus thuringiensis Cry1Ab toxin to the predator Chrysoperla carnea (Neuroptera: Chrysopidae). Environ Entomol 27:1255-1263 (1998).

21 Hilbeck A, Moar WJ, Puztai Carey M, Filippini A and Bigler F, Preymediated effects of Cry1 Ab toxin and protoxin and cry2A protoxin on the predator Chrysoperla carnea. Entomol Exp Appl 91:305-316 (1999).

22 Romeis J, Dutton A and Bigler F, Bacillus thuringiensis toxin (Cry $1 \mathrm{Ab})$ has no direct effect on larvae of the green lacewing Chrysoperla carnea (Stephens) (Neuroptera: Chrysopidae). J Insect Physiol 50:175-183 (2004).

23 Rodrigo-Simón A, de Maagd RA, Avilla C, Bakker PL, Molthoff J, González-Zamora JE, et al, Lack of detrimental effects of Bacillus thuringiensis Cry toxins on the insect predator Chrysoperla carnea: a toxicological, histopathological, and biochemical analysis. Appl Environ Microbiol 72:1595-1603 (2006).

24 Ferry N, Edwards MG, Gatehouse JA and Gatehouse AMR, Plant-insect interactions: molecular approaches to insect resistance. Current opinion in Biotechnology 15:155-161 (2004).

25 Read JW and Haas LW, The baking quality of flour as affected by certain enzymeactions. Further studies concerning potassium bromate and enzyme activity. Cereal Chem 15:59-68 (1938).

26 Hilder VA, Gatehouse AMR, Sheerman SE, Barker RF and Boulter D, A novel mechanism of insect resistance engineered into tobacco. Nature 330:160-163 (1987)

27 Bell HA, Fitches EC, Marris GC, Bell J, Edwards JP, Gatehouse JA, et al, Transgenic GNA expressing potato plants augment the beneficial biocontrol of Laconobia oleracea (Lepidoptera; Noctuidae) by the parasitoid Eulophus pennicornis (Hymenoptera; Eulophidae). Transgenic Res 10:35-42 (2001).

28 De Leo F, Bonadé-Bottino MA, Ceci LR, Gallerani R and Jouanin L, Effects of a mustard trypsin inhibitor expressed in different plants on three lepidopteran pests. Insect Biochem Mol Biol 31:593-602 (2001).

29 Leple JC, Bonade-Bottino M, Augustin S, Pilate G, Lê Tân VD, Delplanque A, et al, Toxicity to Chrysomela tremulae (Coleoptera: Chrysomelidae) of transgenic poplars expressing a cysteine proteinase inhibitor. Mol Breeding 1:319-328 (1995).

30 Winter J and Bergelson J, Diamondback moth compensatory consumption of protease inhibitor-transformed plants. Mol Ecol 10:1069-1074 (2001)

31 De Leo F, Bonadé-Bottino MA, Ceci LR, Gallerani R and Jouanin L, Opposite effects on Spodoptera littoralis larvae of high expression level of a trypsin proteinase inhibitor in transgenic plants. Plant Physiol 118:997-1004 (1998).

32 Broadway RM and Villani MG, Does host range influence susceptibility of herbivorous insects to non-host plant proteinase inhibitors? Entomol Exp Appl 76:355-356 (1995).

33 Jongsma MA, Bakker PL, Peters J, Bosch D and Stiekema WJ, Adaptation of Spodoptera exigua larvae to plant proteinase inhibitors by induction of gut proteinase activity insensitive to inhibition. Proc Natl Acad Sci USA 12:8041-8045 (1995).

34 Bown DP, Wilkinson HS and Gatehouse JA, Differentially regulated inhibitor-sensitive and insensitive protease genes from the phytophagous insect pest, Helicoverpa armigera, are members of complex multigene families. Insect Biochem Mol Biol 27:625-638 (1997).

35 Wu Y, Llewellyn D, Matthews A and Dennis ES, Adaptation of Helicoverpa armigera (Lepidoptera: Noctuidae) to a proteinase inhibitor expressed in transgenic tobacco. Mol Breeding 3:371-380 (1997).

36 Girard C, Bonade-Bottino M, Pham-Delegue MH and Jouanin L, Two strains of cabbage seed weevil (Coleoptera: Curculionidae) exhibit differential susceptibility to a transgenic oilseed rape expressing oryzacystatin I. J Insect Physiol 44:569-577 (1998).

37 Girard C, Le Métayer M, Bonade-Bottino M, Pham-Delegue MH and Jouanin L, High levels of resistance to proteinase inhibitors may be conferred by proteolytic cleavage in beetle larvae. Insect Biochem Mol Biol 28:229-237 (1998).

38 Bolter CJ and Jongsma MA, Colorado potato beetles (Leptinotarsa decemlineata) adapt to proteinase inhibitors induced in potato leaves by methyl jasmonate. J Insect Physiol 41:1071 - 1078 (1995).

39 Bonade-Bottino M, Lerin J, Zaccomer B and Jouanin L, Physiological adaptation explains the insensitivity of Baris coerulescens to transgenic oilseed rape expressing oryzacystatin 1. Insect Biochem Mol Biol 29:131-138 (1999).

40 Edmonds HS, Gatehouse LN, Hilder VA and Gatehouse JA, The inhibitory effects of the cysteine protease inhibitor, oryzacystatin, on digestive proteases and on larval survival and development of the southern corn rootworm (Diabrotica undecempunctata howardi). Entomol Exp Appl 78:83-94 (1996).

41 Burgess EPJ, Lövei GL, Malone LA, Nielsen IW, Gatehouse HS and Christeller JT, Prey-mediated effects of the protease inhibitor aprotinin on the predatory carabid beetle Nebria brevicollis. J Insect Physiol 48:1093-1101 (2002).

42 Ferry N, Jouanin L, Ceci LR, Mulligan EA, Emami K, Gatehouse JA, et al, Impact of oilseed rape expressing the insecticidal serine protease inhibitor, mustard trypsin inhibitor-2, on the beneficial predator Pterostichus madidus. Mol Ecol 14:337-349 (2005).

43 Mochizuki A, Characteristics of digestive proteases in the gut of some insect orders. Appl Entomol Zool 33:401-407 (1998).

44 Lecardonnel A, Chavin C, Jouanin L, Beaujean A, Prevost G and Sangwan-Norreel B, Effects of rice cysteine 1 expression in transgenic potato on Colorado potato beetle larvae. Plant Sci 140:87-98 (1999).

45 Bonadé-Bottino $M$, Défense du colza contre les insectes phytophages déprédateurs: étude d'une stratégie basée sur l'expression d'inhibiteurs de protéases dans la plante. PhD Dissertation, University of Paris-Sud, Orsay, France (1993).

46 Gatehouse AMR, Davison GM, Newell CA, Merryweather A, Hamilton WDO, Burgess EPJ, et al, Transgenic potato plants with enhanced resistance to the tomato moth, Lacanobia oleracea: growth room trials. Mol Breeding 3:49-63 (1997).

47 Mulligan EA, Ferry N, Jouanin L, Walters KFA, Port GR and Gatehouse AMR, Comparing the impact of conventional pesticide and use of a transgenic pest-resistant crop on the beneficial carabid beetle Pterostichus melanarius. Pest Man Sci 62:999-1012 (2006).

48 Bradford MM, A rapid and sensitive method for the quantitation of microgram quantities of protein using the principle of protein-dye binding. Ann Biochem 72:248-254 (1976).

49 Yang Y, Wu Y, Chen S, Devine GJ, Denholm I, Jewess P, et al, The involvement of microsomal oxidases in pyrethroid resistance in Helicoverpa armigera from Asia. Insect Biochem Mol Biol 34:763-773 (2004).

50 Rose R, Barbhaiya L, Rowe R, Rock G and Hodgson E, Cytochrome P-450 associated insecticide resistance and the development of biochemical diagnostic assays in Heliothis virescens. Pestic Biochem Physiol 51:178-191 (1995).

51 Ulrich V and Weber P, The O-dealkylation of 7-ethoxycoumarin by liver microsomes, a direct fluorometric test. Hoppe-Seylers Physiol Chem Bd 353:1171-1177 (1972).

52 Ferran $A$, Bigler $F$ and Lyon JP, Etude des activitiés enzymatiques des glandes salivaires et des intestines de trois insectes prédateurs de pucerons: Chrysoperla carnea Stephens, Chrysoperla perla (Neuropteres, Chrysopidae) et Semidalia 11 notata Sch. (Coleopteres, Coccinellidae). Ann Zool Ecol Animale 8:513-521 (1976).

53 Yazlovetsky IG, Development of artificial diets for entomophagous insects by understanding their nutrition and digestion, in Advances in Insect Rearing for Research and Pest Management, ed. by Anderson TE and Leppla NC. Westview Press, Boulder, CO, pp. 41-62 (1992).

54 Ermicheva FM, Sumenkova VV and Yazlovetskii IG, Changes in intestinal proteases during the post embryonic development of the common aphid lion Chrysopa carnea. J Evol Biochem Physiol 27:145-150 (1991).

55 Ferry N, Raemaekers JM, Majerus MEN, Jounain L, Port G, Gatehouse JA, et al, Impact of oilseed rape expressing the insecticidal cysteine protease inhibitor oryzacystatin on the beneficial predator Harmonia axyridis (multicoloured Asian ladybeetle). Mol Ecol 12:493-504 (2003).

56 De Leo F and Gallerani R, The mustard trypsin inhibitor 2 affects the fertility of Spodoptera littoralis larvae fed on transgenic plants. Insect Biochem Mol Biol 32:489-496 (2002).

57 Rahbe $\mathrm{Y}$, Ferrasson E, Rabesona $\mathrm{H}$ and Quillien L, Toxicity to the pea aphid Acyrthosiphon pisum of anti-chymotrypsin isoforms and fragments of Bowman-Birk protease inhibitors from pea seeds. Insect Biochem Mol Biol 33:299-306 (2003). 
58 Urwin PE, Atkinson $\mathrm{HJ}$, Waller DA and McPherson MJ, Engineered oryzacystatin-1 expressed in transgenic hairy roots confers resistance to Globodera pallida. Plant J 8:121-131 (1995).

59 Rahbe Y, Deraison C, Bonado-Bottino M, Girard C, Nardon C and Jouanin $L$, Effects of the cysteine protease inhibitor oryzacystatin (OC-1) on different aphids and reduced performance of Myzus persicae on OC-1 expressing transgenic oilseed rape. Plant Sci 164:441-450 (2003).

60 Schüler TH, Poppy GM, Kerry BR and Denholm I, Insect-resistant transgenic plants. Trends Biotechnol 16:168-175 (1998).

61 Rumpf S, Frampton C and Chapman B, Acute toxicity of Insecticides to Micromus tasmaniae (Neuroptera: Hemerobiidae) and Chrysoperla carnea (Neuroptera: Chrysopidae): $\mathrm{LC}_{50}$ and $\mathrm{LC}_{90}$ estimates for various test durations. J Econ Entomol 90:1493-1499 (1997).

62 Grafton-Cardwell EE and Hoy MA, Short-term effects of permethrin and fenvalerate on oviposition by Chrysoperla carnea (Neuroptera: Chrysopidae). J Econ Entomol 78:955-959 (1985).

63 Hassan SA, Bigler F, Bogenschutz H, Brown JU, Firth SI, Huang P, et al, Results of the second joint pesticide testing programme by the IOBC/WPRS working group 'Pesticides and Beneficial Arthropods'. ZAngew Entomol 95:151-158 (1983). 